\title{
Information Technology for Modern Marketing
}

\author{
T Rohmawati ${ }^{*}$, H Winata ${ }^{2}$ \\ ${ }^{1}$ Departemen Ilmu Pemerintahan, Universitas Komputer Indonesia, Indonesia \\ 2Departemen Ilmu Komunikasi, Universitas Komputer Indonesia, Indonesia \\ Email: *tatik.rohmawati@email.unikom.ac.id
}

\begin{abstract}
The purposes of this research are to identify marketing strategies using exposure in the online business world, explain the role and understanding of Exposure in the online marketing business, and explain the marketing system in social media influencers. The method used in this research is descriptive method. The results of this study is that exposure could be one of the best way to promote the product. This study discusses about exposure, influencers' social media, barter exposure, barter exposure system in influencers' social media, and the benefits of doing barter exposure in marketing.
\end{abstract}

\section{Introduction}

Barter exposure is a modern payment method that arises today, where an influencer who has a big impact will promote the companies' product. An influencer is someone who acts as an influence giver because his views, advice or opinions can influence purchasing decisions. If this is combined in marketing a business, this will greatly help a company that will do business. It is because the influencer is able to promote the product better because their popularity. In addition, with the help from influencers through social media, brand attachment and consumer loyalty to the product can be maintained [1].

Internet is used by all people in this era to do many activities such as to find information, pleasure, seek profits, and to do a business [2]. The advance in technology helps humans' to do their activities and save their time. Therefore, using media technology to do a promotion is one of the best ways to promote the product. The marketing concept also determines the needs and wants of the desired product or service effectively and efficiently [3]. Since market advertising and promoting an item or service is very diverse, one of the tools that can be used is social media. Social Media is an internet-based application group network using a website and technology [4]. Every social media user can make or exchange information on the application as well. There are social media platforms that have a big influence, such as Instagram, Twitter, Facebook, Snapchat, and others. For marketers, this is a huge potential and opportunity to be used as a marketing communication tool [5].

The purposes of this research are to identify marketing strategies by doing a barter exposure with influencers, and how marketing strategies are carried out by companies. The method used in this research is descriptive method. 


\section{Method}

This research used descriptive method to find out the information related to barter exposure in social media influencers and modern marketing strategies. We also used previous research related to marketing strategies and barter exposure.

\section{Results and Discussion}

The use of social media is not only seen as a place for self-fulfillment but can be a place to do a business. Other than that, social media also can be a place to market the products and give a brief information about a product or service that will be marketted [6]. Nowadays, most company choose an influencer to market their products and do a barter exposure [7]. Influencer will promote companies' products or services in their social media. Therefore, after promoting the products, people will buy the products, especially if the price is cheap with a good condition. The exposure made by influencers is formed in several processes (See Figure $1)$.

\section{Suggested Social Media Metrics Model}

\begin{tabular}{|c|c|c|c|c|}
\hline EXPOSURE & ENGAGEMENT & INFLUENCE & IMPACT & ADVOCACY \\
\hline $\begin{array}{l}\text { Create } \\
\text { potential } \\
\text { audience } \\
\text { exposure to } \\
\text { content \& } \\
\text { message. }\end{array}$ & $\begin{array}{l}\text { Interaction that } \\
\text { occurs in } \\
\text { response to } \\
\text { content on an } \\
\text { owned channel } \\
\text { 'engaging with } \\
\text { you'. } \\
\text { Also earned } \\
\text { social } \\
\text { conversation } \\
\text { 'talking about } \\
\text { you'. }\end{array}$ & $\begin{array}{l}\text { Ability to cause } \\
\text { or contribute to } \\
\text { a change in } \\
\text { opinion or } \\
\text { behavior. }\end{array}$ & $\begin{array}{l}\text { Effect of a } \\
\text { social media } \\
\text { campaign, } \\
\text { program or } \\
\text { effort on the } \\
\text { target } \\
\text { audience. } \\
\text { Also Value - } \\
\text { the financial } \\
\text { impact. }\end{array}$ & $\begin{array}{l}\text { Act of pleading or } \\
\text { making the case for } \\
\text { something. Includes } \\
\text { positive sentiment and } \\
\text { one of } \\
\text { the following: } \\
\text { - A recommendation } \\
\text { - A call to action to } \\
\text { purchase } \\
\text { - Suggested usage } \\
\text { or suggested } \\
\text { change to opinion. }\end{array}$ \\
\hline
\end{tabular}

Figure 1. Social media exposure

1. Exposure, promote the product through messages and content

2. Engagement, interactions that occur in response to the content created.

3. Influence, the ability to changes people's opinion or behaviour.

4. Impact, the effects of social media campaign programs or efforts on the target audience as well the impact on financial value

5. Advocacy, act or make trouble for something including making a statement:
a. Recommendation
b. Action
c. Suggestion

Influencers usually have many followers on social media. However, the more followers that they have, the greater impact that can be given to companies that work with them. It is because many people believe the influencers' opinion and see the product that they promote (See Figure 2). 
International Journal of Research and Applied Technology

1(1)(2021) 90-96

Journal homepage: https://ojs.unikom.ac.id/index.php/injuratech

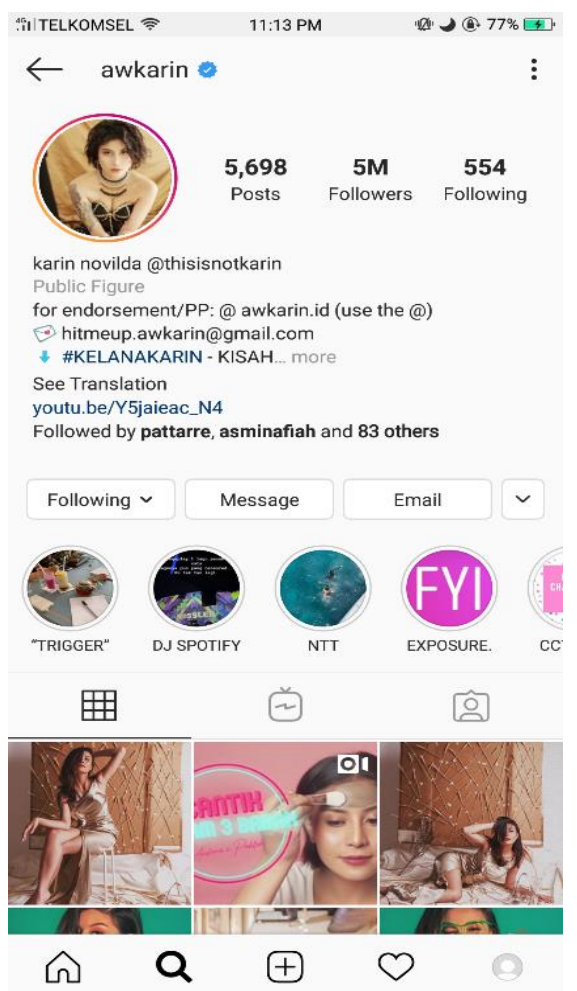

Figure 2. One influencer on Instagram

By posting photos on social media, an influencer usually tags the company in their post. Then, all their followers will know about the company and start to look at the promoted product (See Figure 3).

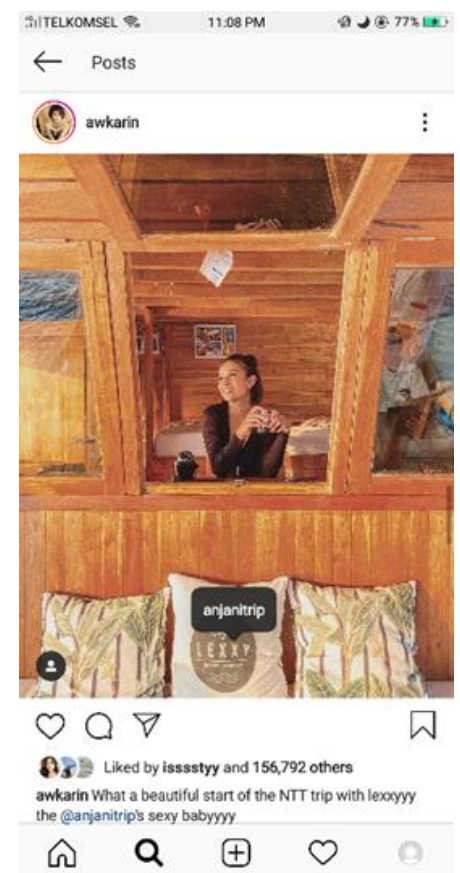

Figure 3. One post influencer is promoting a company 
Usually, companies also have their own social media. So, people could see the companyies's social media and look at their products in more detail (See Figure 4). The influencers have benefit from the company such as money or get the product for free. That way abarter exposure could be achieved (See Figure 4).

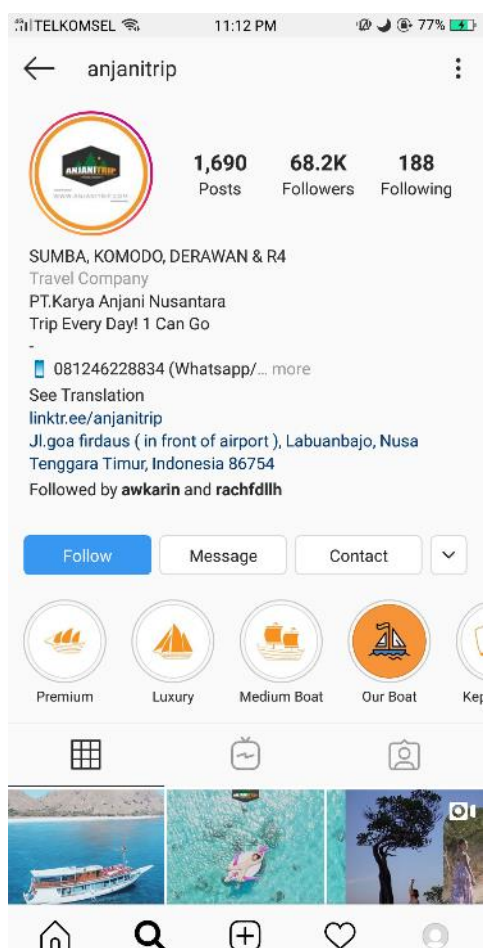

Figure 4. Corporate social media

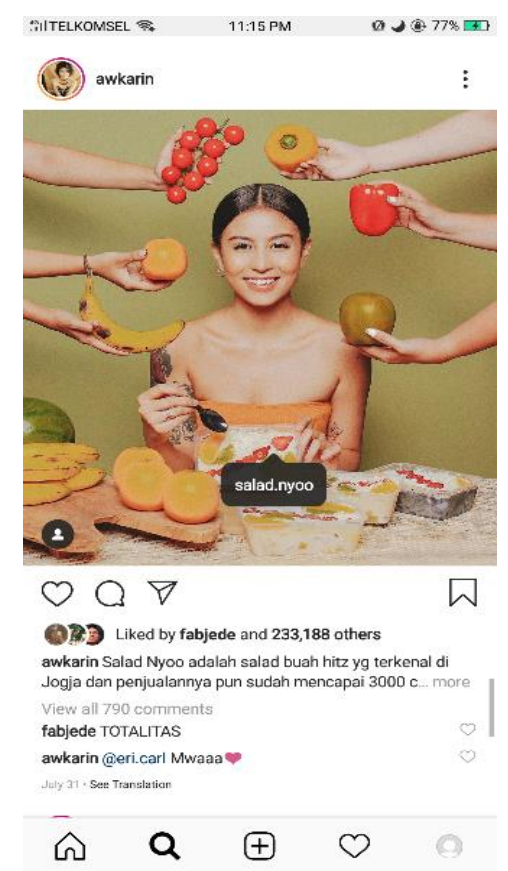

Figure 5. Promotion from influencers 
In exchanging exposure an influencer must respect the companies' value. Therefore, there will be no problem in the barter exposure process (See Figure 6).

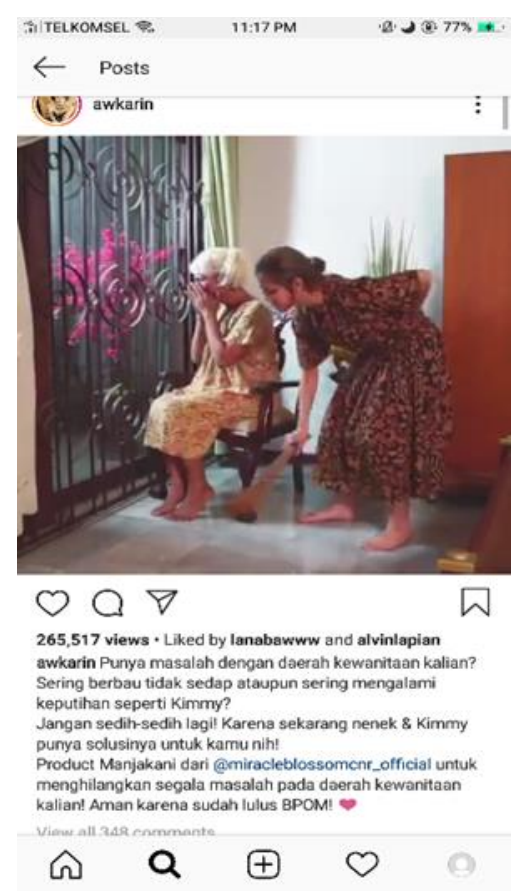

Figure 6. Promote via video

An influencer must be able to create content to promote a company's product or service as creative as possible to get people's attention. That way, the products will be attractive enouogh to get customers' attention (See Figure 7).

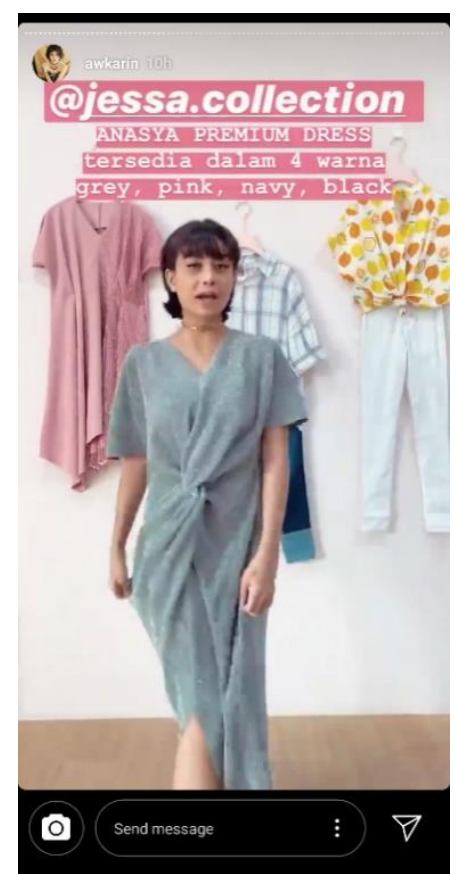

Figure 7. Promote through story feature 
Not only by posting photos or videos, usually an influencer promotes products by visiting the office or shop and sharing his experiences through social media to influence people. Therefore, the sale will be increased and the company get the recognition [8] (See Figure 8).

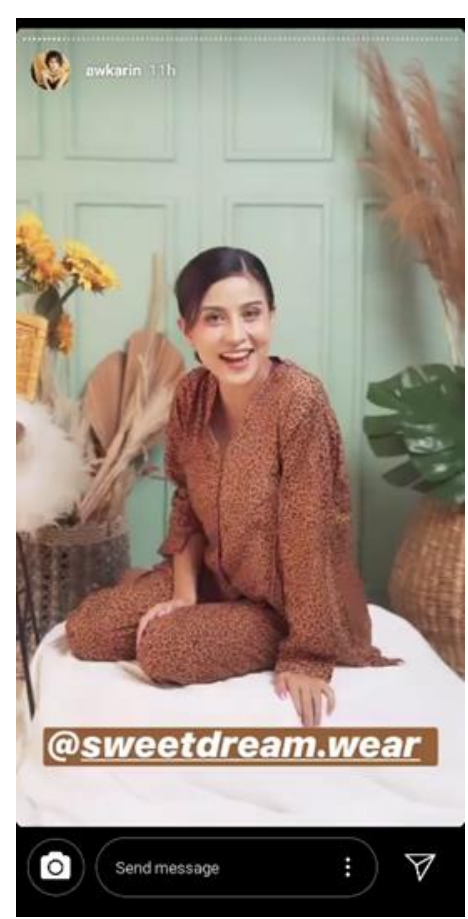

Figure 8. An influencer promotes a product with a visit store

The benefit of the company will be increasing after doing a barter exposure. Besides, an influencer also will get the benefit from the company by getting a product and service provided for the influencer [9-10] (See Figure 9).

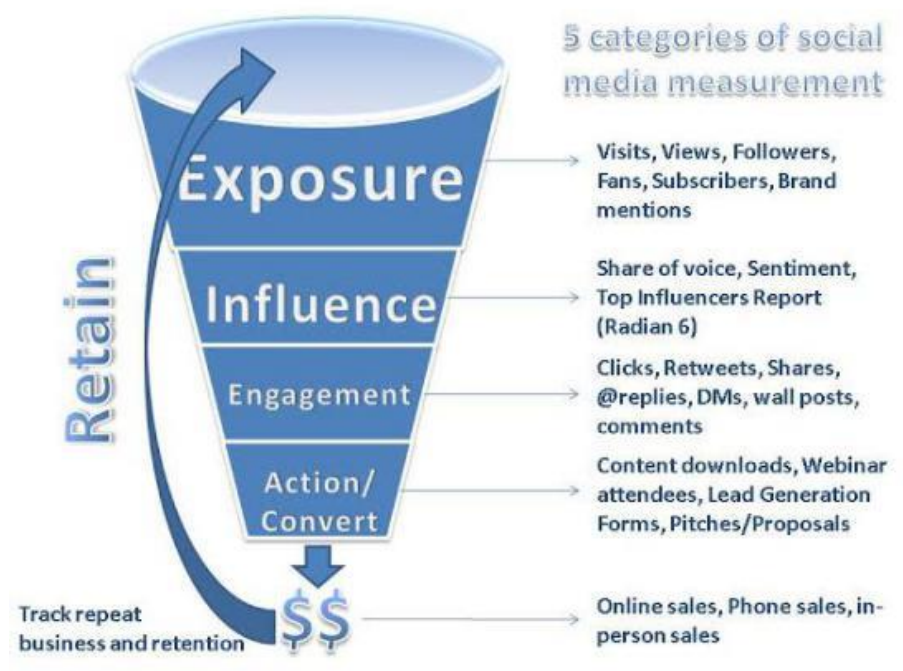

Figure 9. Measurement of social media. 


\section{International Journal of Research and Applied Technology}

1(1)(2021) 90-96

Journal homepage: https://ojs.unikom.ac.id/index.php/injuratech

\section{Conclusion}

It can be concluded that social media can be used as one of marketing tool. Using social media also has a lot of benefit such as increasing the sell value.

\section{Acknowledgement}

Thanks to Prof. Dr. Ir. Eddy Soeryanto Soegoto, Lecturer in Entrepreneurship and Universitas Komputer Indonesia.

\section{References}

[1] Ulfah, I., Sumarwan, U., \& Nurrochmat, D. R. 2016. Marketing mix factors that influence the desire to purchase fruit beverages in the city of Bogor. Indonesian Journal of Business and Entrepreneurship (IJBE), 2(1), pp. 33.

[2] Nasri, R., \& Ikra, M. 2017. Application of Cost Leadership and Differentiation Startegy to Reach A Competitive Benefit (A Case Study Of "Fish Streat" Culinary Business). IMC 2016 Proceedings, 1(1), pp. 1-8

[3] Soegoto, E. S., \& Eliana, E. 2018, August. E-Commerce and Business Social Media Today. In IOP Conference Series: Materials Science and Engineering, 407(1), pp. 012034

[4] Yousaf, S., \& Xiucheng, F. 2018. Halal culinary and tourism marketing strategies on government websites: A preliminary analysis. Tourism Management, 68, pp. 423-443.

[5] Wahyuningtyas, F. M., Achmad, F., \& Zainul, A. 2017. The effect of experiential marketing on satisfaction and its impact on customer loyalty. Russian Journal of Agricultural and Socio-Economic Sciences, 61(1), pp. 10-30

[6] Kadarisman, M. 2019. The influence of government and MUI mediations towards marketing strategy of Warteg and its impact on developing MSMEs in Jakarta, Indonesia. Cogent

Business \& Management, 6(1), pp. 1629096.

[7] Krush, M. T., Sohi, R. S., \& Saini, A. (2015). Dispersion of marketing capabilities: impact on marketing's influence and business unit outcomes. Journal of the Academy of Marketing Science, 43(1), pp. 32-51.

[8] Godey, B., Manthiou, A., Pederzoli, D., Rokka, J., Aiello, G., Donvito, R., \& Singh, R. (2016). Social media marketing efforts of luxury brands: Influence on brand equity and consumer behavior. Journal of business research, 69(12), pp. 5833-5841.

[9] Lehoux, P., Daudelin, G., Williams-Jones, B., Denis, J. L., \& Longo, C. 2014. How do business model and health technology design influence each other? Insights from a longitudinal case study of three academic spin-offs. Research Policy, 43(6), pp. 10251038.

[10] Aichner, T. 2014. Country-of-origin marketing: A list of typical strategies with examples. Journal of Brand Management, 21(1), pp. 81-93. 